\title{
Productivity and Water Expense Efficiency of Rice (Oryza sativa L.) under Different Irrigation Scheduling in South-West Punjab
}

\author{
Sukhveer Singh, Balwinder Singh Dhillon* and Baldev Singh Sidhu
}

College of Agriculture, Guru Kashi University, Talwandi Sabo, Punjab, India

*Corresponding author

\begin{tabular}{|c|}
\hline Keywords \\
\hline $\begin{array}{l}\text { Rice, Grain yield, } \\
\text { Irrigation } \\
\text { scheduling and } \\
\text { water expense } \\
\text { efficiency }\end{array}$ \\
\hline Article Info \\
\hline $\begin{array}{l}\text { Accepted: } \\
\text { 17 June } 2019 \\
\text { Available Online: } \\
\text { 10 July } 2019\end{array}$ \\
\hline
\end{tabular}

\section{Introduction}

Rice (Oryza sativa $\mathrm{L}$.) is an important cereal crop in Asia and contains $74.8 \%$ carbohydrate, $8.4 \%$ protein, $2.6 \%$ fat, amino acids and minerals. In India, rice occupying 43.95 million ha and production of 106.54 million tones rice with average productivity $24.24 \mathrm{q} / \mathrm{ha}$. In Punjab, rice was grown on 2.85 million hectares with a production of 11.27 million tonnes and average yield of $40 \mathrm{q} / \mathrm{ha}$ during 2018 (Anonymous 2018). Rice crop grows well in high humidity, temperature
A field experiment entitled "Effect of irrigation scheduling on performance and water expense efficiency in rice (Oryza sativa L.) in South-west Punjab" was conducted during the rabi season of 2017 at Research Farm of Guru Kashi University, Talwandi Sabo, Bathinda (Punjab). The experiment was laid out in RCBD (Randomized complete block design) with 4 treatments viz., $\mathrm{T}_{1}$ : Continuous standing of irrigation water, $\mathrm{T}_{2}$ : Irrigation one day after infiltration of pounded water, $\mathrm{T}_{3}$ : Irrigation two days after infiltration of pounded water, $\mathrm{T}_{4}$ : Irrigation four days after infiltration of pounded water. The results showed that the application of irrigation one day after infiltration of ponded water recorded significantly higher no. of tillers/hill $(16.12)$, plant height $(129.9 \mathrm{~cm})$, no. of effective tillers/hill (14.9), panicle length $(29.1 \mathrm{~cm})$, number of grains/panicle (204.5), grain yield (77.1 q/ha), straw yield (187.3 q/ha), biological yield (294.9 q/ha) and water expense efficiency $(42.2 \mathrm{~kg} / \mathrm{ha} / \mathrm{cm})$ than other treatments. Application of irrigation one day after infiltration of ponded water do not produced only higher grain yield but also helped to save $27 \%$ irrigation water compared to continuous flooding. The findings can be useful for improving rice productivity with less water consumption in Punjab state. 
2009), leaching of soluble nutrients, blocking of soil microbial activities reduced mineralization have also been reported under continuous flooding of rice (Uphoff and Randriamiharisoa, 2002). Water saving is the main issue in maintaining the sustainability of rice production under scare water conditions (Arif et al., 2012).

Number of alternatives to continuous flooding of rice has been developed by the researches and intermittent irrigation approach can be an applicable strategy that can be used for water saving without any loss in yield of rice. The earlier studies showed $21 \%, 50 \%$ and $21 \%$ decrease in plant growth, flowering and grain yield of rice, respectively due to water deficit (Pirdashti et al., 2004). The intermittent irrigation resulted decrease in water consumption and increased water productivity without any loss of yield (Rezaei and Nahvi 2007 and Rezaei et al., 2010). Sheela and Alexander (1996) reported that water stress affects the chlorophyll content in leaves which lead to inactivation of photosynthesis (Kura-Hotta et al., 1987).

Low availability of nutrients to plant (Wopereis et al., 1999) under water stress conditions decreased in number of tillers, leaf area, dry matter, number of panicles, kernel weight and yield of rice (Beldar et al., 2004). The use of vague irrigation practices by the farmers has resulted in either under irrigation or over irrigation of rice crops leading to low production per unit of applied water. Keeping in view, in adequate canal water availability and poor quality of underground water in south- western districts of Punjab, the present investigation was undertaken to provide information on low water use in rice cultivation. The objectives of the study were: To study the effect of irrigation scheduling on growth and yield of rice. To study the effect of irrigation scheduling on water saving and water expense efficiency in rice.

\section{Materials and Methods}

The present investigation "Effect of irrigation scheduling on performance and water expense efficiency in rice (Oryza sativa L.)" was conducted at experimental farm of University College of Agriculture, Guru Kashi University Talwandi Sabo, Bathinda during rabi season 2017. Talwandi Sabo is located at $29^{\circ} 57 \mathrm{~N}$ latitude and $75^{\circ} 7 \mathrm{E}$ longitudes and altitude ( $213 \mathrm{~m}$ above sea levels). The tract is characterized by semi-arid climate. Maximum temperature is about $45-47^{\circ} \mathrm{C}$ is not uncommon during summer, while freezing temperature accompanied by frost occurrence may be witnessed in the month of December and January. The mean annual rainfall fluctuates around $150 \mathrm{~mm}$, major part of which is during the month of July to November with a few shower of cyclonic rains during winter and spring month. The soil of experimental field was slightly alkaline (pH 7.6) with normal electrical conductivity $\left(0.25 \mathrm{dSm}^{-1}\right)$, low in organic carbon content $(0.30 \%)$ and available nitrogen $(234.3 \mathrm{~kg} / \mathrm{ha})$, medium in available phosphorus $(15.1 \mathrm{~kg} / \mathrm{ha})$ and available potassium $(217.6 \mathrm{~kg} / \mathrm{ha})$. The experiment was laid out in randomized block design with five replications. The treatments comprised of continuous standing of irrigation water, irrigation one day after infiltration of pounded water, irrigation two days after infiltration of pounded water, irrigation four days after infiltration of pounded water.

During the crop growth period, the following observations were recorded from time to time. The height of five randomly selected plants was measured at maturity. Number of tillers was counted manually from randomly selected five plants at maturity in each plot. Tillers bearing panicles were counted and recorded as productive tillers. The length of the panicle from neck node to the apex tip of panicle from the five randomly selected plants in each plot was measured and average value 
was expressed in centimeters. The weight of total produce/plot was recorded after harvest of the crop with help of spring balance. Then the weight of grains per plot was recorded after threshing of the harvested produce from each bundle and mean converted into the grain yield $\mathrm{kg} / \mathrm{ha}$. The bundle weight was taken before threshing and plot wise straw yield was obtained after deducting the grain weight from the whole bundle weight. The straw yield was expressed in $\mathrm{kg} / \mathrm{ha}$. The weight of randomly 1000-grains was recorded from each plot and expressed in g. Harvest index (HI) was calculated by using following formula;

$$
\text { Harvest Index }(\%)=\frac{\text { Grain yield }}{\text { Biological yield }} \times 100
$$

\section{Results and Discussion}

\section{Growth parameters of rice}

Significantly highest plant height was recorded with irrigation was applied one day after infiltration of pounded water $(129.9 \mathrm{~cm})$ which was followed by continuous irrigation (125.9 $\mathrm{cm})$ and was significantly higher than other treatments i.e. irrigation two and four days after infiltration of pounded water (Table 1).

The significantly higher number of tillers/hill (16.12) were recorded in plots receiving irrigation one day after infiltration of pounded water followed by continuous standing of water (14.7). The minimum number of tillers/hill (11.9) was recorded in plots where irrigation was applied four days after infiltration of pounded water.

\section{Yield attributes of rice}

Application of irrigation one day after infiltration of pounded water resulted in maximum number of effective tillers (14.8) per plant and followed by continuous standing of water (13.4) and was significantly higher than other treatments (Table 2). The lowest number of effective tillers (10.9) per plant was recorded in treatment receiving irrigation four days after infiltration of pounded water. Similar results were also reported by Islam (1999), Pal et al., (2013), Thakur et al., (2010), Gani et al., (2002) and Parihar (2004).

Application of irrigation one day after infiltration of pounded water significantly increased rice panicle length $(29.1 \mathrm{~cm})$ as compared to other treatmentsand followed by continuous standing of water $(28.9 \mathrm{~cm})$ (Table $3)$. The lowest panicle length $(26.8 \mathrm{~cm})$ was observed in plots receiving irrigation four days after infiltration of pounded waterand was at par with irrigation applied two days (27.2) after infiltration of pounded water. The variation in the above mentioned growth parameters have also been reported by many research workers Belder et al., (2004), Rezaei and Nahvi (2007)

The different irrigation treatments showed the significant effect on number of grains per panicle. The maximum number of grains per panicle (204.5) was recorded in plots where irrigation was applied one day after infiltration of pounded water followed by continuous flooding (198.8). The minimum number of grains per panicle (183.5) was recorded in plots receiving irrigation four days after infiltration of pounded water. Similar results were also reported by Uppal and Bali (1994), Sarwar et al., (2004).

The data showed a significant effect of different irrigation treatments. Application of irrigation one day after infiltration of pounded water resulted in significantly higher the 1000-grain weight (29.3 g) as compared to other treatments except in continuous flooding which was at par (28.7). The minimum 1000-grain weight (26.9 g) was 
recorded in plots receiving irrigation four days after infiltration of pounded water and was at par with irrigation four days after infiltration of pounded water (27.50). Parihar (2004) suggested that irrigation applied one day after infiltration of pounded water can be considered as standard irrigation schedule.

\section{Yield of rice}

The data revealed that irrigation one day after infiltration of pounded water gave significantly higher grain yield (77.1 q/ha) as compared to other treatments and was 11.2, 25.2 and $35.1 \%$ higher over continuous flooding, irrigation applied two days and four days after infiltration of pounded water, respectively (Table 3 ). The increase in grain yield may be due to increased number of effective tillers/hill, number of grains/panicle and test weight. Similar results were also reported by Dung et al., (2009) and Hao et al., (2007).

The maximum straw yield (187.3 q/ha) was recorded in plots receiving irrigation one day after infiltration of pounded water followed by continuous flooding $(179.2 \mathrm{q} / \mathrm{ha})$. The lowest straw yield (163.9 q/ha) was recorded when irrigation was applied four days after infiltration of pounded water but was at par with irrigation applied two days after infiltration of pounded water (167.1 $\mathrm{q} / \mathrm{ha}$ ).Water stress prevented transfer nutrients to plants which decreased dry matter, leaf area, number of panicle, resulting low straw yield. Similar results were also reported by Parihar (2004).

The data revealed that irrigation applied one day after infiltration of ponded water produced significantly higher biological yield of rice (294.7 q/ha) and was 10, 20.4 and $38.8 \%$ higher over continuous flooded, irrigation applied two days and four days after infiltration of pounded water respectively. Similarly, irrigation applied four days after drainage of infiltration water produced lowest biological yield of rice $(212.3 \mathrm{q} / \mathrm{ha})$. The increased in biological yield of rice may be attributes to increase in plant height, better nutrient availability which resulted in more biomass. The variation in the above mentioned growth parameters have also been reported by Gani et al., (2002).

Table.1 Effect of irrigation scheduling on plant height, number of tillers and number of effective tillers in rice

\begin{tabular}{|l|c|c|c|}
\hline \multicolumn{1}{|c|}{ Treatments } & $\begin{array}{c}\text { Plant height } \\
(\mathbf{c m})\end{array}$ & $\begin{array}{c}\text { No. of tillers/ } \\
\text { hill }\end{array}$ & $\begin{array}{c}\text { Number of effective } \\
\text { tillers/hill }\end{array}$ \\
\hline $\begin{array}{l}\mathbf{T}_{\mathbf{1}}: \text { Continuous standing of } \\
\text { irrigation water }\end{array}$ & 125.9 & 14.7 & 13.4 \\
\hline $\begin{array}{l}\mathbf{T}_{\mathbf{2}}: \text { Irrigation one day after } \\
\text { infiltration of pounded water }\end{array}$ & 129.9 & 16.1 & 14.9 \\
\hline $\begin{array}{l}\mathbf{T}_{\mathbf{3}}: \text { Irrigation two days after } \\
\text { infiltration of pounded water }\end{array}$ & 122.2 & 13.6 & 12.4 \\
\hline $\begin{array}{l}\text { T: } \mathbf{T} \text { Irrigation four days after } \\
\text { infiltration of pounded water }\end{array}$ & 117.9 & 11.9 & 10.9 \\
\hline LSD $(\mathbf{P = 0 . 0 5 )}$ & 1.4 & 0.70 & 0.7 \\
\hline
\end{tabular}


Table.2 Effect of irrigation scheduling on yield parameters of rice

\begin{tabular}{|l|c|c|c|}
\hline \multicolumn{1}{|c|}{ Treatments } & $\begin{array}{c}\text { Panicle length } \\
(\mathbf{c m})\end{array}$ & $\begin{array}{c}\text { Number of } \\
\text { grains/panicle }\end{array}$ & $\begin{array}{c}\text { Test weight } \\
\text { (g) }\end{array}$ \\
\hline $\begin{array}{l}\mathbf{T}_{\mathbf{1}} \text { : Continuous standing of } \\
\text { irrigation water }\end{array}$ & 28.2 & 198.8 & 28.7 \\
\hline $\begin{array}{l}\mathbf{T}_{\mathbf{2}} \text { : Irrigation one day after } \\
\text { infiltration of pounded water }\end{array}$ & 29.1 & 204.5 & 29.3 \\
\hline $\begin{array}{l}\mathbf{T}_{\mathbf{3}} \text { : Irrigation two days after } \\
\text { infiltration of pounded water }\end{array}$ & 27.2 & 188.7 & 27.5 \\
\hline $\begin{array}{l}\mathbf{T}_{\mathbf{4}} \text { : Irrigation four days after } \\
\text { infiltration of pounded water }\end{array}$ & 26.8 & 183.5 & 26.9 \\
\hline \multicolumn{1}{|l|}{$\mathbf{L S D}(\mathbf{P = 0 . 0 5 )}$} & 0.5 & 1.8 & 0.6 \\
\hline
\end{tabular}

Table.3 Effect of irrigation scheduling on productivity of rice

\begin{tabular}{|l|c|c|c|c|}
\hline \multicolumn{1}{|c|}{ Treatments } & $\begin{array}{c}\text { Grain yield } \\
(\mathbf{q} / \mathbf{h a})\end{array}$ & $\begin{array}{c}\text { Straw yield } \\
(\mathbf{q} / \mathbf{h a})\end{array}$ & $\begin{array}{c}\text { Biological } \\
\text { yield (q/ha) }\end{array}$ & $\begin{array}{c}\text { Harvest } \\
\text { Index (\%) }\end{array}$ \\
\hline $\begin{array}{l}\mathbf{T}_{\mathbf{1}} \text { : Continuous standing of } \\
\text { irrigation water }\end{array}$ & 69.3 & 179.3 & 267.9 & 27.9 \\
\hline $\begin{array}{l}\mathbf{T}_{\mathbf{2}} \text { : Irrigation one day after } \\
\text { infiltration of pounded water }\end{array}$ & 77.1 & 187.3 & 294.7 & 29.1 \\
\hline $\begin{array}{l}\mathbf{T}_{\mathbf{3}} \text { : Irrigation two days after } \\
\text { infiltration of pounded water }\end{array}$ & 61.6 & 167.1 & 244.7 & 26.9 \\
\hline $\begin{array}{l}\mathbf{T}_{\mathbf{4}} \text { : Irrigation four days after } \\
\text { infiltration of pounded water }\end{array}$ & 57.0 & 163.9 & 212.3 & 25.8 \\
\hline \multicolumn{1}{|c|}{ LSD (P=0.05) } & 2.2 & 3.8 & 14.8 & 0.4 \\
\hline
\end{tabular}

Table.4 Irrigation water applied and water expense efficiency under different irrigation treatments in rice

\begin{tabular}{|l|c|c|}
\hline \multicolumn{1}{|c|}{ Treatment } & $\begin{array}{c}\text { Irrigation water } \\
\text { applied }(\mathbf{c m})\end{array}$ & $\begin{array}{c}\text { Water expense } \\
\text { efficiency } \mathbf{( k g / h a / c m})\end{array}$ \\
\hline $\begin{array}{l}\mathbf{T}_{\mathbf{1}} \text { : Continuous standing of irrigation } \\
\text { water }\end{array}$ & 302.4 & 22.9 \\
\hline $\begin{array}{l}\mathbf{T}_{\mathbf{2}} \text { : Irrigation one day after infiltration of } \\
\text { pounded water }\end{array}$ & 182.4 & 42.2 \\
\hline $\begin{array}{l}\mathbf{T}_{\mathbf{3}} \text { : Irrigation two days after infiltration } \\
\text { of pounded water }\end{array}$ & 152.5 & 40.4 \\
\hline $\begin{array}{l}\mathbf{T}_{\mathbf{4}} \text { : Irrigation four days after infiltration } \\
\text { of pounded water }\end{array}$ & 137.5 & 41.7 \\
\hline \multicolumn{1}{|l}{$\mathbf{L S D}(\mathbf{P}=\mathbf{0 . 0 5})$} & 0.1 & 1.2 \\
\hline
\end{tabular}


The maximum percent harvest index (29.1) was recorded in plots receiving irrigation one day after infiltration of ponded water followed by continuous flooding (27.9). The minimum percent harvest index (25.79) observed in plots receiving irrigation four days after infiltration of ponded water.

\section{Irrigation water applied and water expense efficiency}

The maximum quantity of water $(302.5 \mathrm{~cm})$ applied under continuous irrigation and was significantly higher than other treatments (Table 4). The minimum quantity of water was $(137.5 \mathrm{~cm})$ when irrigation was applied four days after infiltration of pounded water. The maximum water expense efficiency (42.2 $\mathrm{kg} / \mathrm{ha} / \mathrm{cm}$ ) was recorded when irrigation was applied one day after infiltration of pounded water and was at par i.e. $41.7 \mathrm{~kg} / \mathrm{ha} / \mathrm{cm}$ in case of irrigation applied four days after infiltration of pounded water. The minimum water expense efficiency $(22.9 \mathrm{~kg} / \mathrm{ha} / \mathrm{cm})$ was recorded under continuous irrigation.

In conclusion, Irrigation applied one day after infiltration of pounded water in rice gave maximum grain yield $(77.1 \mathrm{q} / \mathrm{ha})$ as well as straw yield (187.3 q/ha). Application of irrigation water one day after infiltration of pounded water significantly increased plant height, number of effective tillers/hill, number of grains/panicle and biological yield as compared to other treatments. Irrigation applied one day after infiltration of pounded water saved $27 \%$ irrigation water over continuous flooding. Application of irrigation water one day after infiltration of pounded water resulted in maximum water expense efficiency $(42.2 \mathrm{~kg} / \mathrm{cm})$.

\section{References}

Anonymous (2018). Kharif crop outlook 2017/2018. pp-24.

Arif, C., Setiawan, B.I., Mizoguchi, M and
Doi, R (2012). Estimation of water balance components in paddy fields under non-flooded irrigation regimes by using excel solver. Journal of Agronomy 11(2):53-59.

Belder, P., Bouman B.AM., Cabangon, R.G., Lu, E.J.P., Ouilang; Y.H., Li, J.H., Spiertz, J. and Tuong, T.P. (2004). Effect of water-saving irrigation on rice yields and water-use in typical lowland conditions in Asia. Agriculture and Water Management, 65(3): 193-210.

Dung, N.V., Canh, N.T., Tiep, C.A., Dung, N.T., Binh, H.T.T, Son, N.T. and Giang, N.T. (2009). Effective water management in rice cultivation and water resource conservation. Journal of Science and Development, 7(2): 151158.

Gani A., Rahman, A., Rustam, D. and Hengsdijk, H. (2002). Synopsis of water management experiments in Indonesia, Water wise rice production (IRRI), pp 29-38.

Hao, Z., Shenfeng Z., Jianchang Y., Jianhua, Z. and Zhiqin, W (2007). Postanthesis moderate wetting drying improves both quality and quantity of rice yield. Agronomy Journal 100(3): 726-734.

International Rice Research Institute (2002). Rice Almanac, $3^{\text {rd }}$ Edition (Gramene Reference ID 8379).

Pal, V., Singh, M. M., Kumar, R. and Verma, S.S. (2013). Response of irrigation scheduling on scented rice. Bioinfolet, 10(4C): 1528-1530.

Parihar, S.S. (2004). Effect of crop establishment method, tillage, irrigation and nitrogen on production potential of rice-wheat cropping system. Indian Journal of Agronomy 49(1): 1-5.

Sharma, P. K (1989). Effect of period moisture stress on water-use efficiency in wetland rice. Oryza, 26: 252257.

Uphoff, N and Randriamiharisoa, R (2002). Reducing water use in irrigated rice 
production with the Madagascar system of rice intensification (SRI). In: Bouman B. A., Hengsdijk H., Hardy B., Bindraban P. S., Thuong T.P., and Ladha J. K. (Eds.), Water-wise rice production. Proceedings of the international workshop on waterwise rice production, 8-11 April 2002, Los Baños, Philippines. Los BañosPhilippines: International Rice Research Institute, 71-87 pp.

Uppal, H. S. and Bali, A(1994). Effect of scheduling and cut-off date of irrigation on yield and quality of rice (Oryza sativa) in a non-cracking soil. Indian Journal of Agronomy39(4): 628-630.

Wassman, R., Jagadish, S.V.K., Heuer, S., Ismail, A., Redona, E., Serraj, R., Singh, R. K., Howell, G., Pathak, H and Sumfleth, K (2009). Climate change affecting rice production: the physiological and agronomic basis for possible adaptation strategies. In: Donald L. Sparks, (Eds.), Advances in Agronomy, Vol. 101. Burlington: Academic Press, 59-122 pp.

\section{How to cite this article:}

Sukhveer Singh, Balwinder Singh Dhillon and Baldev Singh Sidhu. 2019. Productivity and Water Expense Efficiency of Rice (Oryza sativa L.) under Different Irrigation Scheduling in South-West Punjab. Int.J.Curr.Microbiol.App.Sci. 8(07): 2115-2121. doi: https://doi.org/10.20546/ijcmas.2019.807.254 